\title{
Detection and Characterization of Qol-Resistant Phytophthora capsici Causing Pepper Phytophthora Blight in China
}

Dicheng Ma, Jiangong Jiang, Leiming He, Kaidi Cui, Wei Mu, and Feng Liu, ${ }^{\dagger}$ Shandong Provincial Key Laboratory for Biology of Vegetable Diseases and Insect Pests, College of Plant Protection, Shandong Agricultural University, Tai'an, Shandong 271018, China

\begin{abstract}
Phytophthora capsici is a highly destructive plant pathogen that has spread worldwide. To date, the quinone outside inhibitor (QoI) azoxystrobin has been the choice of farmers for managing this oomycete. In this study, the sensitivity of $90 \mathrm{P}$. capsici isolates collected from Yunnan, Fujian, Jiangxi, Zhejiang, and Guangdong in southern China to azoxystrobin was assessed based on mycelial growth, sporangia formation, and zoospore discharge. Furthermore, the mitochondrial cytochrome $b$ $(c y t b)$ gene from azoxystrobin-sensitive and -resistant $P$. capsici isolates was compared to investigate the mechanism of QoI resistance. The high values for effective concentration to inhibit $50 \%$ of mycelial growth and large variation factor obtained provide strong support for the existence of azoxystrobin-resistant subpopulations in wild populations. The

resistance frequency of $P$. capsici to azoxystrobin was greater than $40 \%$. Sensitive $P$. capsici isolates were strongly suppressed on V8 medium plates containing azoxystrobin supplemented with salicylhydroxamic acid at $50 \mu \mathrm{g} \mathrm{ml}^{-1}$, whereas resistant isolates grew well under these conditions. Multiple alignment analysis revealed a missense mutation in the cytb gene that alters codon 137 (GGA to AGA), causing an amino acid substitution of glycine to arginine (G137R). The fitness of the azoxystrobin-sensitive isolate is similar to that of the G137R mutant. Additionally, the $P$. capsici isolates used in this study exhibited decreased sensitivity to two other QoI fungicides (pyraclostrobin and famoxadone). Necessary measures should be taken to control this trend of resistance to QoI that has developed in P. capsici in southern China.
\end{abstract}

Phytophthora capsici Leonian, a highly destructive and widely distributed plant oomycete pathogen (Koç 2017), can infect many important vegetable crops, including lima bean, tomato, snap bean, eggplant, all cucurbits, and pepper, causing root, fruit, and foliar diseases (Granke et al. 2012; Lamour et al. 2012). Environmental conditions suitable for infestation lead to devastating crop production losses (Liu et al. 2018). Indeed, Phytophthora blight of pepper is a serious disease in southern China (Li et al. 2007; Ma et al. 2013; Yang et al. 2009) that is being aggravated on an annual basis. Due to the lack of appropriate resistant varieties, producers currently rely heavily on the integration of several agricultural measures and the use of synthetic fungicides, with strobilurin fungicides playing an important role in managing diseases caused by Phytophthora spp. (Bhai and Anjali 2015).

Strobilurin fungicides were developed to protect a wide range of crops from all major fungal and oomycete pathogens (Ojiambo et al. 2010; Thind et al. 2004), and azoxystrobin, pyraclostrobin, and famoxadone, which belong to this chemical group, have been registered for the control of $P$. capsici in China (http://www.chinapesticide. org.cn). Regarding the mechanism of action, these fungicides bind to center of the cytochrome bc1 complex, which inhibits mitochondrial respiration and blocks the electron transport chain, resulting in adenosine triphosphate (ATP) depletion (Asadollahi et al. 2013). However, the $c$ cytochrome $b$ (cytb) gene encoded by mitochondrial DNA has a high mutation frequency, facilitating development of resistance to quinone outside inhibitors (QoI) by these fungi (Jia et al. 2008). In fact, according to the Fungicide Resistance Action Committee (FRAC), these compounds have a high risk of resistance development and, after their introduction to

${ }^{\dagger}$ Corresponding author: Feng Liu; E-mail: fliu@sdau.edu.cn

Funding: The National Key Research Development Program of China supported this study (2016YFD0200500).

*The $\boldsymbol{e}$-Xtra logo stands for "electronic extra" and indicates that one supplementary table and three supplementary figures are published online.

Accepted for publication 6 March 2018.

C 2018 The American Phytopathological Society the market, field resistance in different crop-pathogen systems was widely reported (Gisi et al. 2002). Two regions of the $c y t b$ gene are generally considered responsible for resistance to strobilurins (i.e., single-codon changes at positions 127 to 147 and 275 to 296) (Jordan et al. 1999; Geier et al. 1992). In all, 11 point mutations in these regions have been related to QoI resistance (Sierotzki et al. 2000). In addition, inhibition of mitochondrial election transfer by QoI dramatically increases reactive oxygen species production, and cells are then induced to express alternative oxidase (AOX) and to initiate an alternative pathway to promote resistance to strobilurin fungicides (Wood and Hollomon 2003). Therefore, AOX expression and single-point mutations are mainly responsible for resistance to strobilurins. Accordingly, to develop and implement an antiresistance strategy, the mechanism underlying resistance must be identified.

Since its first release to the market in 1996, azoxystrobin (developed by Syngenta) has been registered for use in various crops worldwide (Gisi et al. 2002; Guo et al. 2015). This chemical inhibits mycelial growth, spore germination, and conidial production, and its protection, treatment, and systemic activity have been characterized (Burnett et al. 2010; Matheron and Porchas 2000). Nonetheless, some pathogens have reportedly developed resistance to azoxystrobin, including Colletotrichum siamense, Pyricularia oryzae, Zymoseptoria tritici, and Cercospora beticola (Hu et al. 2015; Oliveira et al. 2015; Stewart et al. 2014; Vaghefi et al. 2016). Although azoxystrobin is a very effective fungicide for the control of Phytophthora capsici, in vitro sensitivity studies based on encysted zoospores and mycelia have indicated that $P$. capsici in China (Qian et al. 2006) and the United States (Matheron and Porchas 2000) is not highly sensitive to azoxystrobin. In April 2004, the European and Mediterranean Plant Protection Organization stated that $P$. capsici might have a tendency toward developing resistance to azoxystrobin, though no study thus far has explored the possible resistance mechanism of $P$. capsici to QoI.

The specific objectives of this study were to (i) evaluate the sensitivity of $P$. capsici isolates at several life stages to azoxystrobin and (ii) investigate the azoxystrobin resistance mechanism in $P$. capsici from southern China.

\section{Materials and Methods}

$\boldsymbol{P}$. capsici isolates and chemicals. In total, 90 single-spore isolates were obtained from pepper samples infected with Phytophthora pepper blight in southern China from 2015 to 2017 (Supplementary Table S1). These strains were cultured on V8 juice agar medium 
( $800 \mathrm{ml}$ of distilled water, $17 \mathrm{~g}$ of agar, $1 \mathrm{~g}$ of $\mathrm{CaCO}_{3}$, and $200 \mathrm{ml}$ of V8 juice) for 4 days at $25^{\circ} \mathrm{C}$ to supply inoculum. Mycelial plugs were stored long term in sterile 2-ml tubes at $18^{\circ} \mathrm{C}$ (Hu et al. 2013).

Technical-grade azoxystrobin (95\% active ingredient [a.i.]; Shandong Weifang Rainbow Chemical Co., Ltd.), pyraclostrobin (98\% a. i.; Shandong United Pesticide Industry Co., Ltd.), and famoxadone (98.5\% a.i.; Shaanxi Meibang Pesticide Co., Ltd.) were used in biological activity assays. These strobilurin fungicides were dissolved in methanol $\left(1 \times 10^{4} \mu \mathrm{g} \mathrm{ml}^{-1}\right)$ and stored at $4^{\circ} \mathrm{C}$ in the dark until required. Salicylhydroxamic acid (SHAM, 99\% a.i.; Acros Organics) was dissolved in methanol to prepare a stock solution $\left(20 \mathrm{mg} \mathrm{ml}^{-1}\right.$ ).

Sensitivity of $\boldsymbol{P}$. capsici isolates to strobilurin fungicides. The sensitivities of mycelial growth, sporangia formation, and zoospore discharge to strobilurins were determined using all $90 \mathrm{P}$. capsici isolates. A general linear model (SAS Institute) was performed to calculate the effective concentration to inhibit $50 \%$ of mycelial growth $\left(\mathrm{EC}_{50}\right)$ values for the inhibitory effect of azoxystrobin on the various life stages of $P$. capsici.

The sensitivity of mycelial growth to the three strobilurin fungicides was assessed using a previously described procedure (Sun et al. 2010). The final concentrations of fungicides in V8 medium were as follows: $0,0.64,1.6,4,10$, and $25 \mu \mathrm{g} \mathrm{ml}^{-1}$ for azoxystrobin; $0,25.6,64,160,400$, and $1,000 \mu \mathrm{g} \mathrm{ml}^{-1}$ for pyraclostrobin; and 0 , $62.5,125,250,500$, and $1,000 \mu \mathrm{g} \mathrm{ml}^{-1}$ for famoxadone. To prevent the induction of alternative respiration by the pathogens, we added SHAM at $50 \mu \mathrm{g} \mathrm{ml}^{-1}$ to the medium. After incubation at $25^{\circ} \mathrm{C}$ for 4 days, the colony diameters of the isolates were measured. Each treatment had three replicate plates and the entire experiment was repeated three times.

We examined the bioactivity of azoxystrobin on sporangia formation following the procedure described by Matheron and Porchas (2000). Ten mycelial plugs (5 $\mathrm{mm}$ in diameter) of each isolate were cut from V8 cultures and transferred to a series of fresh Petri dishes containing $15 \mathrm{ml}$ of azoxystrobin solution at different concentrations $\left(0,0.5,1,2,4\right.$, and $\left.8 \mu \mathrm{g} \mathrm{ml}^{-1}\right)$. These Petri dishes were incubated for $48 \mathrm{~h}$ at $25^{\circ} \mathrm{C}$ under a 12 -h photoperiod, and the number of sporangia on each mycelial plug was counted microscopically. Three replications were involved for each fungicide concentration and isolate combination, and all experiments were carried out three times.

According to a protocol of Miao et al. (2015), 10 mycelial plugs of each isolate that had been induced to produce sporangia were placed into a series of Petri dishes containing $15 \mathrm{ml}$ of sterile water supplemented with azoxystrobin to reach final concentrations of $0,1.25$, $2.5,5,10$, and $20 \mu \mathrm{g} \mathrm{ml}^{-1}$. These Petri dishes were kept for $30 \mathrm{~min}$ at $25^{\circ} \mathrm{C}$ after a 30 -min incubation at $4^{\circ} \mathrm{C}$. We counted the number of empty sporangia under a light microscope $(\times 10$ magnification $)$ for three replicate plates per treatment. All tests were conducted three times.

Synergism between azoxystrobin and SHAM. Synergism between azoxystrobin and SHAM was tested using 39 randomly selected $P$. capsici strains. Mycelial plugs cut from the margin of the colony were transferred to V8 plates amended with different azoxystrobin concentrations $\left(0,25.6,64,160,400\right.$, and $\left.1,000 \mu \mathrm{g} \mathrm{ml}^{-1}\right)$ or azoxystrobin $\left(0,0.64,1.6,4,10\right.$, and $\left.25 \mu \mathrm{g} \mathrm{ml}^{-1}\right)$ in the presence of
SHAM at $50 \mu \mathrm{g} \mathrm{ml}^{-1}$. After incubation for 4 days at $25^{\circ} \mathrm{C}$, the colony diameters of the isolates were measured in two perpendicular directions. Each treatment consisted of three replicate plates and the entire trial was repeated three times.

DNA extraction, polymerase chain reaction, and sequencing. After being grown on V8 medium for 5 days, $P$. capsici strain mycelia were harvested, and total DNA was extracted and purified using the protocol of Ristaino et al. (1998). The $c y t b$ gene fragments were amplified from total DNA using the polymerase chain reaction (PCR) primers $c y t b$ f $\left(5^{\prime}\right.$-ATTGTCCAACCCAACCTAAT- $\left.3^{\prime}\right)$ and cytbr (5'-TCGTTAGCCGGTATTATGTT-3'). Primer 3 (http://bioinfo. ut.ee/primer3-0.4.0/primer3/) was used to design the primers in this study according to the reference $c y t b$ gene sequence of $P$. capsici (GenBank accession MG570037).

The amplification reaction volume $(50 \mu \mathrm{l})$ contained $5 \mu \mathrm{l}$ of $10 \times$ EasyTaq DNA Polymerase Buffer, 50 ng of DNA template, $1 \mu \mathrm{l}$ of each primer, $2.5 \mathrm{U}$ of EasyTaq DNA polymerase, and $2.5 \mathrm{mM}$ each deoxynucleotide triphosphate (dNTP). Amplifications were performed using the Gene Amp PCR System 9700 thermal cycler with the following program: $94^{\circ} \mathrm{C}$ for $5 \mathrm{~min}$; followed by 30 cycles at $94^{\circ} \mathrm{C}$ for $30 \mathrm{~s}, 51.3^{\circ} \mathrm{C}$ for $30 \mathrm{~s}$, and $72^{\circ} \mathrm{C}$ for $1 \mathrm{~min}$; and a final extension at $72^{\circ} \mathrm{C}$ for $10 \mathrm{~min}$ before cooling to $4^{\circ} \mathrm{C}$. The amplification products were stained with ethidium bromide after electrophoresis through a $1.5 \%$ agarose gel in $1 \times$ Tris-acetate-EDTA buffer. We cloned the purified PCR products using the procedure described by Ishii et al. (2001). After sequencing by the Shanghai Biosune Biotechnology Company, the $c y t b$ gene sequences were translated into amino acid sequences using the general code at the National Center for Biotechnology Information GenBank.

Characterization of the azoxystrobin-resistant mutants. After sequencing, the cytb sequences obtained from azoxystrobin-resistant and -sensitive isolates were compared. Four isolates of $P$. capsici with low resistance to azoxystrobin and a genetic mutation were identified: YN-6, FJ-2, JX-5, and GD-1 (Supplementary Fig. S1). Two other isolates, YN-19 (sensitive isolate) and FJ-4 (highly resistant isolate), were also selected.

These six $P$. capsici strains were incubated on V8 medium for 4 days at $10,18,25,30$, and $37^{\circ} \mathrm{C}$. The colony diameters of the isolates were measured in two perpendicular directions. The entire experiment was performed three times, and three replicate plates were included for each treatment.

According to the description mentioned above (Matheron and Porchas 2000), mycelia of YN-6, FJ-2, JX-5, GD-1, YN-19, and FJ-4 were induced to produce sporangia, and the number of sporangia on the V8 medium per square centimeter was counted. In total, 20 mycelial plugs were cut from each isolate, including 10 from the margin of the culture and 10 from the neighborhood of the initial inoculation. Each isolate involved two replicate plates, and the experiment was performed three times.

The virulence of each isolate was evaluated on detached pepper leaves (susceptible cultivar Pepper Champion) using the method of Pang et al. (2013), with slight modifications. The fourth expanded leaves of pepper were sterilized with $1 \%$ sodium hypochlorite solution for $5 \mathrm{~min}$, rinsed three times with sterile water, and air dried. Next, the backs of the leaves were artificially inoculated with

Table 1. Sensitivity of 90 Phytophthora capsici isolates to azoxystrobin obtained from five provinces in southern China

\begin{tabular}{|c|c|c|c|c|c|c|c|c|c|c|}
\hline \multirow[b]{3}{*}{ Location } & \multirow[b]{3}{*}{$N^{\mathbf{z}}$} & \multicolumn{9}{|c|}{$\mathrm{EC}_{50}$ for inhibition of $\left(\mu \mathrm{g} \mathrm{ml}^{-1}\right)^{y}$} \\
\hline & & \multicolumn{3}{|c|}{ Mycelial growth } & \multicolumn{3}{|c|}{ Sporangia production } & \multicolumn{3}{|c|}{ Zoospore discharge } \\
\hline & & Range & Mean \pm SD & VF & Range & Mean \pm SD & VF & Range & Mean \pm SD & VF \\
\hline Yunnan & 24 & $0.22-39.85$ & $4.41 \pm 0.86 b$ & 181.36 & $1.00-8.21$ & $3.39 \pm 0.35 \mathrm{a}$ & 7.97 & $2.25-22.06$ & $6.63 \pm 0.23 \mathrm{ab}$ & 9.81 \\
\hline Fujian & 22 & $0.42-198.98$ & $27.38 \pm 0.73 \mathrm{a}$ & 473.76 & $0.68-5.31$ & $3.03 \pm 0.61 \mathrm{a}$ & 7.80 & $3.37-4.63$ & $3.92 \pm 0.30 \mathrm{a}$ & 1.37 \\
\hline Jiangxi & 16 & $2.42-45.02$ & $17.42 \pm 0.23 \mathrm{ab}$ & 18.60 & $2.57-9.71$ & $4.77 \pm 0.66 \mathrm{a}$ & 3.78 & $10.74-15.12$ & $12.65 \pm 0.29 \mathrm{~b}$ & 1.41 \\
\hline Zhejiang & 14 & $0.78-20.61$ & $7.39 \pm 0.70 \mathrm{~b}$ & 26.42 & $3.56-6.17$ & $4.95 \pm 0.76 \mathrm{a}$ & 1.73 & $3.16-9.34$ & $6.96 \pm 0.92 \mathrm{ab}$ & 2.96 \\
\hline Guangdong & 14 & $0.37-5.08$ & $1.89 \pm 0.84 \mathrm{~b}$ & 13.73 & $2.57-4.44$ & $3.50 \pm 0.93 \mathrm{a}$ & 1.73 & $2.88-8.39$ & $6.26 \pm 0.70 \mathrm{ab}$ & 2.91 \\
\hline
\end{tabular}

${ }^{y} \mathrm{EC}_{50}=$ effective concentration to inhibit $50 \%$ of mycelial growth. Mean values followed by the same letter in the columns were not significantly different in

Fisher's least significant difference test at $P=0.05 . \mathrm{SD}=$ standard deviation. $\mathrm{VF}=$ variation factor $=$ highest $\mathrm{EC}_{50}$ value divided by the lowest $\mathrm{EC}_{50}$ value. ${ }^{\mathrm{z}}$ Number of isolates. 
mycelial plugs of each $P$. capsici isolate and transferred to a humid chamber for 7 days at $25^{\circ} \mathrm{C}$ to promote the development of disease. Disease severity was evaluated by measuring the lesion. In total, 12 replicate leaves were tested for each treatment, and this experiment was conducted three times.

The virulence of each isolate on pepper seedlings (Pepper Champion) was mainly assessed using a described protocol (Glosier et al. 2008). Briefly, $5 \mathrm{ml}$ of a zoospore suspension $\left(1 \times 10^{4}\right.$ zoospores $\left.\mathrm{ml}^{-1}\right)$ of the $P$. capsici isolate was used to inoculate each pepper seeding at the four-true-leaf stage. The inoculated plants were grown for 7 days in a greenhouse at $25^{\circ} \mathrm{C}$ under a 12 -h photoperiod and relative humidity was maintained at approximately $80 \%$. The potted pepper plants were graded on the basis of disease in the entire plant. Each treatment consisted of 30 seedlings, and this assay was repeated three times.

Data analysis. All data from this study were analyzed using the SAS statistical software package (version 9.2; SAS Institute). Linear regression analysis of the percent relative growth against the $\log _{10}$
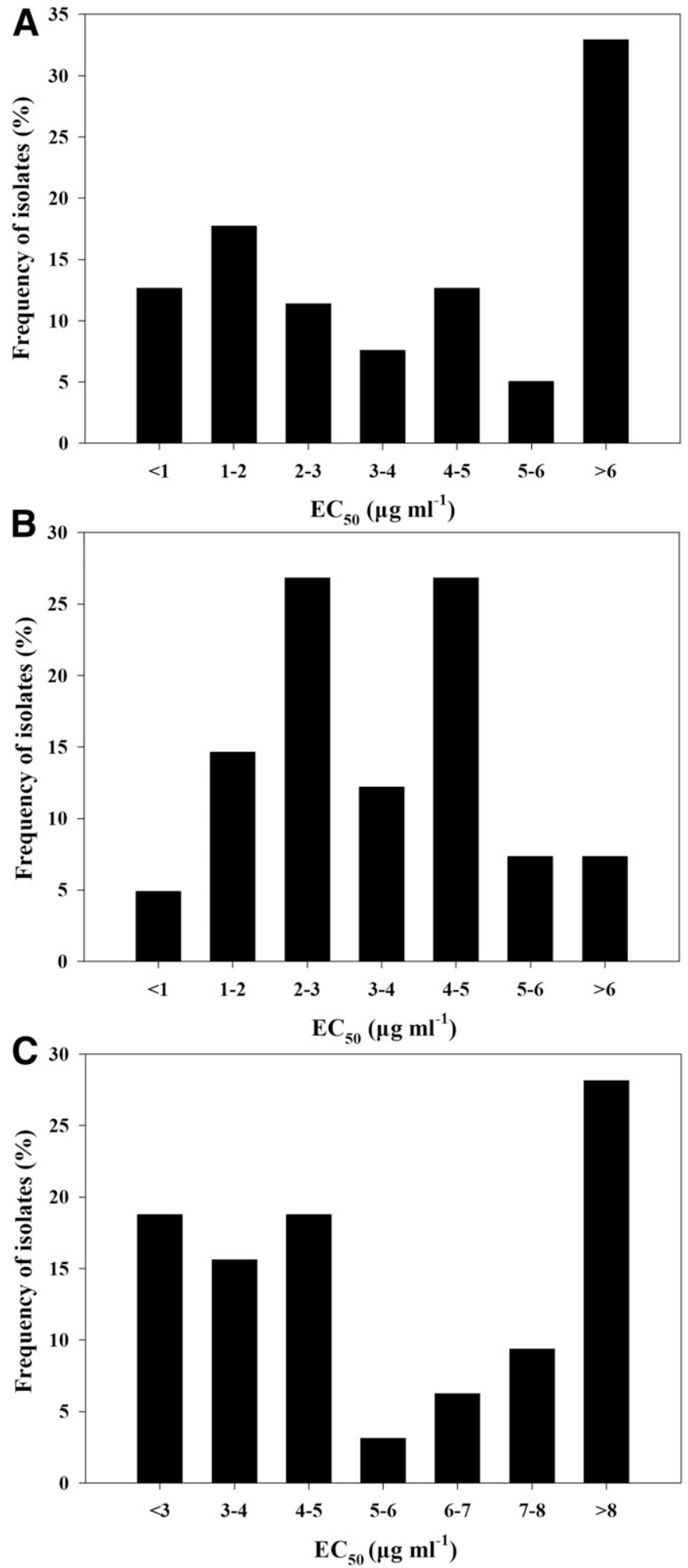

Fig. 1. Distribution of effective concentration to inhibit $50 \%$ of mycelial growth $\left(\mathrm{EC}_{50}\right)$ values for azoxystrobin against 90 Phytophthora capsici isolates obtained from southern China based on A, mycelial growth; B, sporangia formation; and C, zoospore discharge. 
fungicide concentration was performed to calculate $\mathrm{EC}_{50}$ values. One-way analysis of variance was utilized to detect significance between treatments. Subsequently, Fisher's least significant difference test $(P=0.05)$ was used to compare means between different treatments.

\section{Results}

Sensitivity of $\boldsymbol{P}$. capsici isolates to azoxystrobin. The sensitivities of all 90 single-spore $P$. capsici isolates to azoxystrobin were determined based on mycelial growth, sporangia formation, and zoospore discharge. Sensitivities of isolates collected from Yunnan, Fujian, Jiangxi, Zhejiang, and Guangdong were compared (Table 1). The frequency distributions of the $\mathrm{EC}_{50}$ values for several developmental stages tested in this study were not a unimodal curve (Fig. 1).

For mycelial growth, a significant difference $(P=0.02)$ in mean $\mathrm{EC}_{50}$ values of several groups of isolates to azoxystrobin was detected. The mean $\mathrm{EC}_{50}$ values for isolates from Yunnan, Fujian, Jiangxi, Zhejiang, and Guangdong were 4.41, 27.38, 17.42, 7.39, and $1.89 \mu \mathrm{g} \mathrm{ml}^{-1}$, respectively. Variation factors (the highest $\mathrm{EC}_{50}$ value divided by the lowest $\mathrm{EC}_{50}$ value) ranged from 13.73 to 473.76. In sporangia formation assays, no evident variation $(P=$ 0.41 ) was detected in the sensitivities of the various groups of isolates to azoxystrobin, with mean $\mathrm{EC}_{50}$ values of 3.39 , 3.03, 4.77, 4.95, and $3.50 \mu \mathrm{g} \mathrm{ml}^{-1}$ for the isolates from Yunnan, Fujian, Jiangxi, Zhejiang, and Guangdong, respectively. The largest variation factor was 7.97. However, a significant difference $(P=0.01)$ was found for the sensitivity of zoospore discharge among the isolates of different origins; the mean $\mathrm{EC}_{50}$ values for Yunnan, Fujian, Jiangxi, Zhejiang, and Guangdong were 6.63, 3.92,12.65, 6.96, and $6.26 \mu \mathrm{g} \mathrm{ml}^{-1}$, respectively. The variation factors ranged from 1.37 to 9.81 (Table 1 ).

The baseline sensitivity of $54 \mathrm{P}$. capsici strains to azoxystrobin obtained from Guangdong was $0.9649 \mu \mathrm{g} \mathrm{ml}^{-1}$ (Jiang and Wang 2008) and the $\mathrm{EC}_{50}$ values of the resistant isolates were 5 to 10 times higher than that of the sensitive isolates (Zhao et al. 2008). Consequently, the sensitivity of the $P$. capsici isolates to azoxystrobin was classified as follows: $\mathrm{EC}_{50}$ value $<4.8 \mu \mathrm{g} \mathrm{ml}^{-1}$ was sensitive, 4.8 $\mu \mathrm{g} \mathrm{ml}^{-1}<\mathrm{EC}_{50}$ value $<24 \mu \mathrm{g} \mathrm{ml}^{-1}$ was low resistance, $24 \mu \mathrm{g} \mathrm{ml}^{-1}$ $<\mathrm{EC}_{50}$ value $<120 \mu \mathrm{g} \mathrm{ml}^{-1}$ was moderate resistance, and $\mathrm{EC}_{50}$ value $>120 \mu \mathrm{g} \mathrm{ml}^{-1}$ was high resistance. In total, 90 single-spore $P$. capsici isolates collected from southern China between 2015 and 2017 were used to determine sensitivity to azoxystrobin with the mycelium growth rate method (Table 1). The resistance frequency to azoxystrobin was $43.21 \%$, with sensitive isolates accounting for $56.79 \%$ of the total, low resistant isolates accounting for $35.80 \%$, moderately resistant isolates accounting for $6.17 \%$, and highly resistant isolates accounting for $1.23 \%$ (Supplementary Fig. S2).

Sensitivity of $\boldsymbol{P}$. capsici isolates to pyraclostrobin and famoxadone. The sensitivity profiles of $90 \mathrm{P}$. capsici isolates to pyraclostrobin and famoxadone were also assessed by mycelial growth. With regard to pyraclostrobin, a significant difference $(P=0.03)$ in mean $\mathrm{EC}_{50}$ values among the Yunnan, Fujian, Jiangxi, Zhejiang, and Guangdong populations was observed (201.43, 122.67,
407.21, 306.42, and $194.06 \mu \mathrm{g} \mathrm{ml}^{-1}$, respectively), with variation factors ranging from 4.61 to 10.70 . However, it should be noted that the mean $\mathrm{EC}_{50}$ values of the $P$. capsici isolates obtained from different regions to famoxadone were very similar $(P=0.51)$. The mean $\mathrm{EC}_{50}$ values for the Yunnan, Fujian, Jiangxi, Zhejiang, and Guangdong populations were 461.62, 326.40, 424.80, 202.88, and $418.91 \mu \mathrm{g} \mathrm{ml}^{-1}$; the variation factors ranged from 7.03 to 61.38 (Table 2).

Synergism between azoxystrobin and SHAM. To evaluate in vitro synergism between azoxystrobin and SHAM, the sensitivity to azoxystrobin of $39 \mathrm{P}$. capsici isolates selected randomly from our isolate collection was characterized (Fig. 2). The inhibitory effect of azoxystrobin dramatically increased in the presence of SHAM at $50 \mu \mathrm{g} \mathrm{ml}^{-1}$, whereas the inhibitory activity of azoxystrobin alone was very low based on mycelial growth due to synergism, even at a concentration of $200 \mu \mathrm{g} \mathrm{ml}^{-1}$. The synergistic coefficients $\left[\mathrm{EC}_{50}\right.$ (azoxystrobin) alone/EC 50 (azoxystrobin) + SHAM] of these isolates ranged from 7.57 to 687 .

Molecular analysis of azoxystrobin-resistant isolates. After sequencing, a fragment ( $925 \mathrm{bp}$ ) of the mitochondrial $c y t b$ gene of $P$. capsici was obtained. Based on comparisons with sequences available in databases, this $P$. capsici gene fragment represents approximately $85 \%$ of the entire $c y t b$ gene.

Four azoxystrobin-resistant mutants (YN-6, FJ-2, JX-5, and GD-1) were selected after comparing the $c y t b$ sequences of each isolate. Multiple alignment of the partial $c y t b$ gene nucleotide sequences suggested that a $\mathrm{T}$ to $\mathrm{C}$ change at nucleotide positions 404,707 , and 725 was presented in FJ-2, JX-5, and GD-1, respectively, whereas a $\mathrm{G}$ to $\mathrm{A}$ change at nucleotide position 366 was presented in YN-6. However, the G137R substitution caused by the nucleotide change from GGA to AGA was found only in YN-6 (Fig. 3). Furthermore, we did not detect any other known mutations such as G143A and F129L in the azoxystrobin-resistant isolates in this study.

Characterization of azoxystrobin-resistant mutants. For all $P$. capsici isolates tested in this work, $25^{\circ} \mathrm{C}$ was considered the optimal temperature for mycelial growth. Additionally, isolate YN-6 grew equally as fast as the sensitive isolate $\mathrm{YN}-19$ at 10, 18, 25, 30, and $37^{\circ} \mathrm{C}$. These results revealed that the G137R mutant exhibits normal growth at all tested temperatures. In contrast, the highly resistant isolate FJ-4 grew more slowly than the sensitive isolate YN-19 at all temperatures tested, except for $30^{\circ} \mathrm{C}$, demonstrating that this mutation is not beneficial for mycelial growth. Compared with the sensitive isolate, the other three isolates (GD-1, FJ-2, and JX-5) grew at various rates at the different temperatures tested (Table 3).

In in vitro tests, sporangia production by $\mathrm{YN}-6$ was similar to that by the sensitive isolate $\mathrm{YN}-19$. In contrast, the highly resistant isolate FJ-4 produced significantly $(P=0.02)$ fewer sporangia than the sensitive isolate YN-19 did. Furthermore, no significant difference in sporangia production was detected between GD-1, FJ-2, JX-5, and the sensitive isolate YN-19 (Table 4).

All six isolates caused typical symptoms on both detached pepper leaves and entire potted pepper plants and were found to be virulent (Supplementary Fig. S3). In addition, no significant difference in

Table 2. Sensitivity of Phytophthora capsici isolates to pyraclostrobin and famoxadone as obtained from southern China

\begin{tabular}{|c|c|c|c|c|c|c|c|}
\hline \multirow[b]{3}{*}{ Location } & \multirow[b]{3}{*}{$N^{\mathbf{z}}$} & \multicolumn{6}{|c|}{$\mathrm{EC}_{50}$ for inhibition of $\left(\mu \mathrm{g} \mathrm{ml}^{-1}\right)$ of mycelial growth } \\
\hline & & \multicolumn{3}{|c|}{ Pyraclostrobin } & \multicolumn{3}{|c|}{ Famoxadone } \\
\hline & & Range & Mean \pm SD & VF & Range & Mean \pm SD & VF \\
\hline Yunnan & 24 & $67.09-399.29$ & $201.43 \pm 0.14 b$ & 5.95 & $26.78-996.25$ & $461.62 \pm 0.35 \mathrm{a}$ & 37.17 \\
\hline Fujian & 22 & $23.36-179.92$ & $122.67 \pm 0.36 b$ & 7.70 & $10.49-644.45$ & $326.40 \pm 0.60 \mathrm{a}$ & 61.38 \\
\hline Jiangxi & 16 & $107.42-910.07$ & $407.21 \pm 0.49 \mathrm{a}$ & 8.47 & $117.42-825.38$ & $424.80 \pm 0.72 \mathrm{a}$ & 7.03 \\
\hline Zhejiang & 14 & $57.54-617.79$ & $306.42 \pm 0.59 \mathrm{ab}$ & 10.70 & $11.79-391.29$ & $202.88 \pm 0.99 \mathrm{a}$ & 33.16 \\
\hline Guangdong & 14 & $78.39-361.35$ & $194.06 \pm 0.15 b$ & 4.61 & $25.62-900.72$ & $418.91 \pm 0.21 \mathrm{a}$ & 35.18 \\
\hline
\end{tabular}

${ }^{y} \mathrm{EC}_{50}=$ effective concentration to inhibit $50 \%$ of mycelial growth. Mean values followed by the same letter in the columns were not significantly different in

Fisher's least significant difference test at $P=0.05 . \mathrm{SD}=$ standard deviation. $\mathrm{VF}=$ variation factor $=$ highest $\mathrm{EC}_{50}$ value divided by the lowest $\mathrm{EC}_{50}$ value.

${ }^{\mathrm{z}}$ Number of isolates. 
pathogenicity was observed between the G137R mutant YN-6 isolate and the sensitive YN-19 isolate. The other three mutants (GD-1, FJ2, and JX-5) exhibited pathogenicity similar to that of the sensitive isolate $\mathrm{YN}-19$ (Table 4).

\section{Discussion}

In the present study, the sensitivities to azoxystrobin of 90 P. capsici strains collected from southern China in 2015 to 2017 were determined at different life stages. Among the developmental stages of $P$. capsici examined, the formation of sporangia was inhibited to the largest extent by azoxystrobin (Table 1). This observation was in full agreement with the results of Qian et al. (2006), who conducted studies using 45 single-spore $P$. capsici isolates from Jiangsu and Anhui, China. The large variation factors based on mycelial growth, sporangia formation, and zoospore discharge showed a high degree of variation in sensitivity among the isolates. Based on the high $\mathrm{EC}_{50}$ values observed, we speculate that azoxystrobin-resistant subpopulations exist in the field. If QoI fungicides continue to be

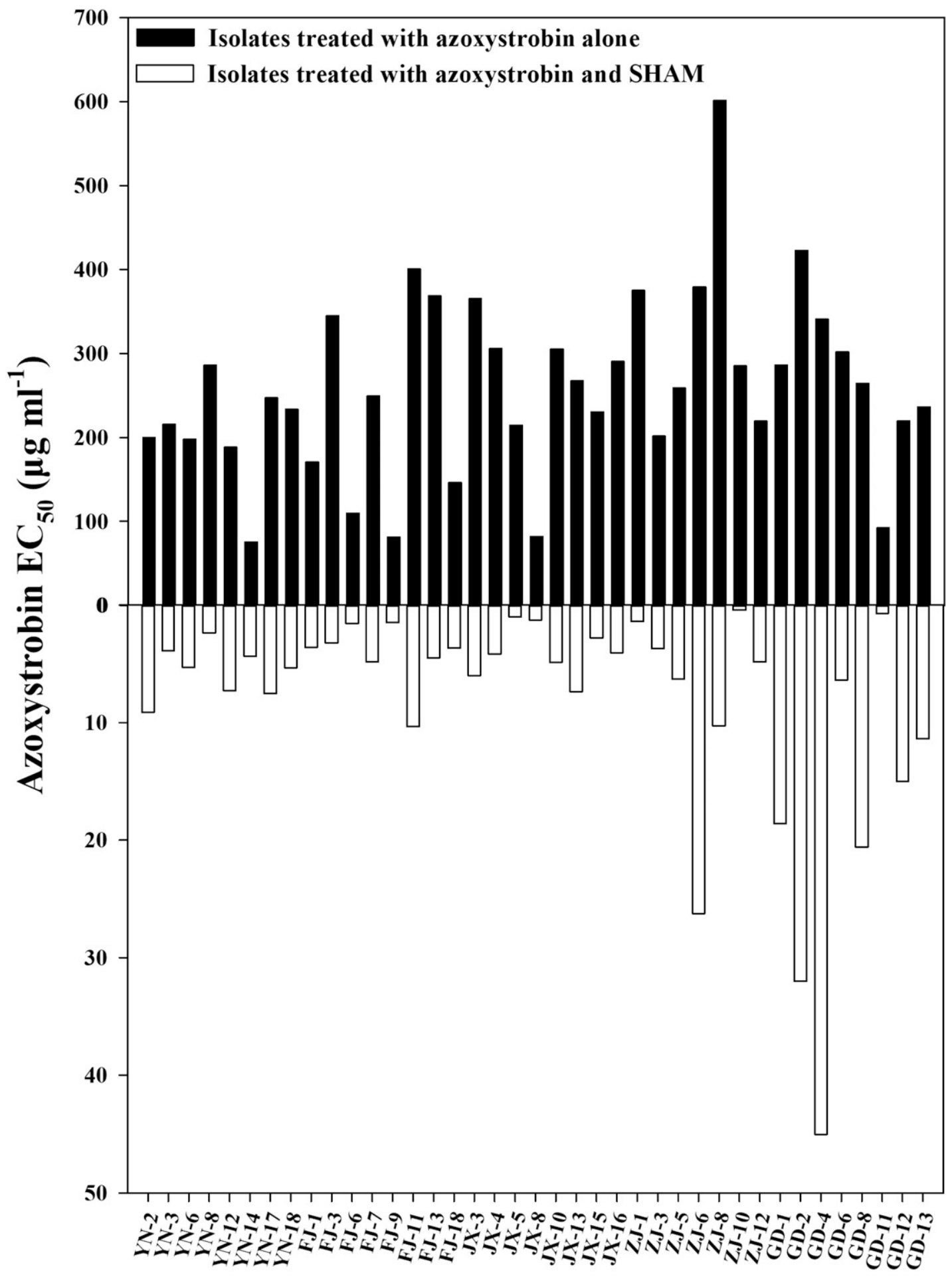

39 isolates of Phytophthora capsici

Fig. 2. Sensitivity of 39 Phytophthora capsici isolates to azoxystrobin or azoxystrobin in the presence of salicylhydroxamic acid (SHAM) at $50 \mu \mathrm{gl} \mathrm{ml}^{-1}$. Sensitivity was based on mycelial growth on $\mathrm{V} 8$ medium. $\mathrm{EC}_{50}=$ effective concentration to inhibit $50 \%$ of mycelial growth. 
applied, resistance will likely be preserved in the population after establishment (Owati et al. 2017).

In our work, SHAM at $50 \mu \mathrm{g} \mathrm{ml}^{-1}$ was used to inhibit AOX activity in P. capsici. According to our findings, mycelial growth inhibition by azoxystrobin with SHAM at $50 \mu \mathrm{g} \mathrm{ml}^{-1}$ was superior to that of azoxystrobin alone (Fig. 2). When cultured on V8 medium amended with azoxystrobin and SHAM, sensitive isolates were clearly distinguished from the resistant isolate. The results from this in vitro synergism test between azoxystrobin and SHAM were in accordance with the conclusion of Qian et al. (2006). The alternative pathway, which was initially found in plants and later in fungi and oomycetes, is considered to be one of the causes of pathogen resistance to strobilurins (Ziogas et al. 1997). The efficiency of ATP synthesis through the alternative pathway was approximately $40 \%$ (Joseph-Horne et al. 2001).

Azoxystrobin-resistant field isolates of $P$. capsici detected in commercial pepper greenhouses in southern China were characterized in this study. FRAC states that three mutations in the $c y t b$ gene of plant pathogens are responsible for resistance to QoI. This selection process is qualitative, and the F129L, G137R, and G143A substitutions are all based on single-nucleotide changes in the $c y t b$ gene. Nevertheless, only one G137R mutant was screened in this study (Fig. 3). To the best of our knowledge, resistance to QoI due to G137R substitution has only been reported in Pyrenophora tritici-repentis, albeit at a very low frequency (Sierotzki et al. 2007). Thus, we believe that the present study is the first to report a G137R mutant in Phytophthora capsici. Our future work will focus on whether other point mutations in the $c y t b$ gene result in azoxystrobin resistance in the field. According to $\mathrm{FRAC}$, the resistance factors $\left(\mathrm{RF}=\right.$ the $\mathrm{EC}_{50}$ of the resistant isolate/the $\mathrm{EC}_{50}$ of the sensitive wild-type isolate) associated with F129L, G137R, and G143A varied. According to FRAC, the RF of the G143A mutant is generally greater than 100 , whereas RF of the G137R and F129L mutants are always between 5 and 15, and only a few RF are more than 50. Our finding of an RF value of $\mathrm{YN}-6$ (19.5) was consistent with this conclusion. A previous study revealed that the G143A and F129L substitutions do not affect the function of the bc1 complex, though G137R seriously impacts the enzymatic activity of the complex and, thus, inhibits cellular respiration (Gisi et al. 2002). Additionally, fungi containing G137R can, to some extent, be controlled by QoI fungicides, although at lower levels than wild-type sensitive isolates (Owati et al. 2017). These problems require further study.

Interestingly, we did not detect any of the previously described point mutations of azoxystrobin-resistant strains of $P$. capsici in our research. This phenomenon was recently reported in Botrytis cinerea (Ishii et al. 2009), in which no G143A substitution was found when five isolates resistant to QoI were examined. Fernández-Ortuño et al. (2008) have suggested that typical cytb gene mutations are not responsible for QoI resistance in Podosphaera fusca. Ishii et al. (2009) also reported that the instability and inequality of mutated

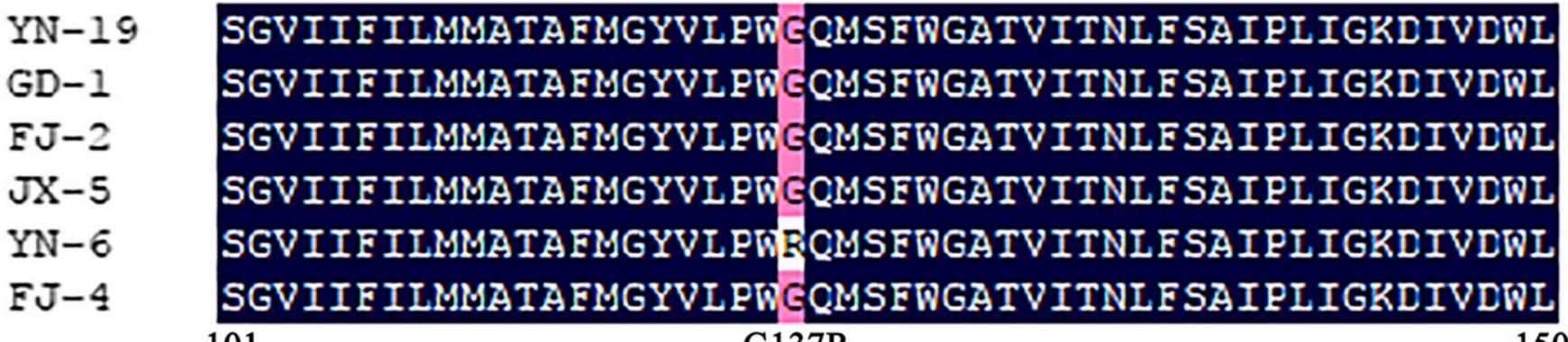

G137R

Fig. 3. Multiple alignment of deduced amino acid sequences of the cytochrome $b$ gene of six Phytophthora capsici isolates, including YN-19, GD-1, FJ-2, JX-5, YN-6, and FJ-4. Dark gray highlighted areas represent $100 \%$ identity.

Table 3. Mycelial growth rate of azoxystrobin-resistant Phytophthora capsici mutants on V8 media at various temperatures

\begin{tabular}{lrcrcc}
\hline & \multicolumn{4}{c}{ Colony diameter $(\mathbf{m m}) \pm \mathbf{S D}^{\mathbf{y}}$} \\
\cline { 2 - 6 } Isolate $^{\mathbf{z}}$ & \multicolumn{1}{c}{$\mathbf{1 0}^{\circ} \mathbf{C}$} & $\mathbf{1 8}^{\circ} \mathbf{C}$ & $\mathbf{2 5}^{\circ} \mathbf{C}$ & $\mathbf{3 0}^{\circ} \mathbf{C}$ \\
\hline YN-19 & $15.00 \pm 0.41 \mathrm{a}$ & $40.00 \pm 0.41 \mathrm{a}$ & $56.25 \pm 0.25 \mathrm{a}$ & $50.75 \pm 0.44 \mathrm{ab}$ & $2.00 \pm 0.64 \mathrm{a}$ \\
GD-1 & $15.25 \pm 0.63 \mathrm{a}$ & $36.50 \pm 0.65 \mathrm{~b}$ & $51.75 \pm 0.85 \mathrm{~b}$ & $47.25 \pm 0.65 \mathrm{ab}$ & $1.75 \pm 0.96 \mathrm{a}$ \\
FJ-2 & $14.50 \pm 0.29 \mathrm{a}$ & $40.50 \pm 0.87 \mathrm{a}$ & $50.25 \pm 0.03 \mathrm{~b}$ & $51.50 \pm 0.96 \mathrm{a}$ & $1.00 \pm 0.29 \mathrm{~b}$ \\
JX-5 & $9.75 \pm 0.48 \mathrm{~b}$ & $39.75 \pm 0.85 \mathrm{a}$ & $48.75 \pm 0.44 \mathrm{~b}$ & $50.00 \pm 0.91 \mathrm{ab}$ & $2.00 \pm 0.91 \mathrm{a}$ \\
YN-6 & $13.50 \pm 0.50 \mathrm{a}$ & $39.75 \pm 0.85 \mathrm{a}$ & $56.00 \pm 0.08 \mathrm{a}$ & $50.50 \pm 0.44 \mathrm{ab}$ & $1.50 \pm 0.58 \mathrm{ab}$ \\
FJ-4 & $7.00 \pm 0.58 \mathrm{c}$ & $36.00 \pm 0.41 \mathrm{~b}$ & $41.25 \pm 0.48 \mathrm{c}$ & $46.50 \pm 0.65 \mathrm{~b}$ & $1.00 \pm 0.48 \mathrm{~b}$ \\
\hline
\end{tabular}

${ }^{y}$ Colony diameter was measured 4 days post inoculation. Values followed by the same letter within a column do not differ significantly $(P<0.05)$. SD $=$ standard deviation.

${ }^{\mathrm{z}} \mathrm{GD}-1, \mathrm{FJ}-2, \mathrm{JX}-5$, and YN-6 were azoxystrobin-resistant mutants of $P$. capsici, whereas YN-19 was a sensitive isolate and FJ-4 was a highly resistant isolate.

Table 4. Fitness of azoxystrobin-resistant Phytophthora capsici mutants compared with the sensitive isolate ${ }^{z}$

\begin{tabular}{|c|c|c|c|}
\hline \multirow[b]{2}{*}{ Isolate } & \multirow{2}{*}{$\frac{\text { In vitro }}{\text { Number of sporangia }\left(\times 10^{4} / \mathrm{cm}^{2}\right) \pm \mathrm{SD}}$} & \multicolumn{2}{|c|}{ In vivo } \\
\hline & & $\operatorname{ALA}\left(\mathrm{cm}^{2}\right) \pm \mathrm{SD}$ & $\mathbf{L A P}(\%) \pm \mathrm{SD}$ \\
\hline YN-19 & $0.41 \pm 0.58 \mathrm{a}$ & $17.23 \pm 0.36 a b$ & $37.20 \pm 0.23 \mathrm{a}$ \\
\hline GD-1 & $0.49 \pm 0.17 \mathrm{a}$ & $17.31 \pm 0.53 \mathrm{ab}$ & $28.50 \pm 0.14 \mathrm{a}$ \\
\hline $\mathrm{FJ}-2$ & $0.35 \pm 0.11 \mathrm{ab}$ & $17.94 \pm 0.40 \mathrm{a}$ & $32.25 \pm 0.16 \mathrm{a}$ \\
\hline JX-5 & $0.47 \pm 0.79 \mathrm{a}$ & $17.91 \pm 0.60 \mathrm{a}$ & $25.85 \pm 0.15 \mathrm{a}$ \\
\hline YN-6 & $0.44 \pm 0.41 \mathrm{a}$ & $16.00 \pm 0.54 b$ & $37.20 \pm 0.18 a$ \\
\hline FJ-4 & $0.21 \pm 0.04 \mathrm{~b}$ & $15.93 \pm 0.76 b$ & $38.77 \pm 0.20 \mathrm{a}$ \\
\hline
\end{tabular}

${ }^{\mathrm{z}}$ Values followed by the same letter within a column do not differ significantly $(P<0.05) . \mathrm{SD}=$ standard deviation, ALA $=$ average lesion area on detached pepper leaves, and LAP = lesion area percentage on potted pepper plants. 
sequences in the $c y t b$ gene are heavily influenced by the dynamic nature of mitochondria, which also possess mechanisms to repair detrimental mitochondrial DNA mutations.

Identification of the characteristics of resistant isolates is important for fungicide resistance risk assessment (Miao et al. 2016), and the fitness of the isolate carrying the G137R mutation was as good as that of the sensitive isolate (Tables 3 and 4). The G137R mutation conferred strong adaptive traits in several life stages, including sporangia production, mycelial growth, and pathogenicity. The adaptability of the G137R mutation-containing isolate indicates that it has a high survival rate in the field and can successfully infect plants and remain competitive. Under selection pressure by azoxystrobin, this azoxystrobin-resistant subpopulation might occupy a dominant position in the field population. Thus, monitoring G137R mutation in field populations of Phytophthora capsici is especially crucial due to the strong survival characteristics of YN-6. Because the molecular methods used to detect fungicide resistance are much quicker than conventional methods (Miao et al. 2016), different PCR-based methods should be developed to monitor the shift in the fungicide sensitivity of $P$. capsici field populations, such as cleaved amplified polymorphic sequence and PCR restriction fragment length polymorphism methods.

In the current study, we found that all the $P$. capsici strains also exhibited decreased sensitivity to pyraclostrobin and famoxadone (Table 2). To avoid the rapid development of field resistance, QoI should be applied in combination with fungicides with different modes of action (Owati et al. 2017) and sprayed preventatively according to the recommended labeled rate rather than after disease has developed (Kitchen et al. 2016). In addition, we recommend that producers withdraw the use of QoI in regions where resistant strains have already occurred. If these guidelines are not followed in practice, $P$. capsici will face additional selection pressure. Currently, the pepper-planting area in China occupies approximately $8.0 \times 10^{5}$ ha (Geng et al. 2011), and the development of resistance in $P$. capsici to QoI will seriously damage the industry.

\section{Literature Cited}

Asadollahi, M., Szojka, A., Fekete, E., Karaffa, L., Takács, F., Flipphi, M., and Sándor, E. 2013. Resistance to QoI fungicide and cytochrome b diversity in the Hungarian Botrytis cinerea population. J. Agric. Sci. Technol. 15: 397-407.

Bhai, R. S., and Anjali, C. R. 2015. Evaluation of strobilurin fungicides Ergon $44.3 \%$ (w/w) [Kresoxim methyl $500 \mathrm{~g} \mathrm{~L}^{-1} \mathrm{SC}$ ] and RIL-070/FI (72WP) against Phytophthora capsici infection in black pepper. J. Spices Aromat. Crops 24:73-82.

Burnett, A. L., Lalancette, N., and McFarland, K. A. 2010. Effect of QoI fungicides on colonization and sporulation of Monilinia fructicola on peach fruit and blossom blight cankers. Plant Dis. 94:1000-1008.

Fernández-Ortuño, D., Torés, J. A., De, V. A., and Pérez-García, A. 2008. Field resistance to QoI fungicides in Podosphaera fusca is not supported by typical mutations in the mitochondrial cytochrome $b$ gene. Pest Manage. Sci. 64: 694-702.

Geier, B. M., Schägger, H., Brandt, U., Colson, A. M., and Von, G. J. 1992. Point mutation in cytochrome $\mathrm{b}$ of yeast ubihydroquinone: Cytochrome-c oxidoreductase causing myxothiazol resistance and facilitated dissociation of the iron-sulfur subunit. Eur. J. Biochem. 208:375-380.

Geng, S. S., Chen, B., Zhang, X. F., and Sun, J. T. 2011. Hot pepper breeding development and its varieties' distribution in China. J. China Capsicum 9:1-4, 9.

Gisi, U., Sierotzki, H., Cook, A., and Caffery, A. M. 2002. Mechanisms influencing the evolution of resistance to Qo inhibitor fungicides. Pest Manage. Sci. 58:859-867.

Glosier, B. R., Ogundiwin, E. A., Sidhu, G. S., Sischo, D. R., and Prince, J. P. 2008. A differential series of pepper (Capsicum annuum) lines delineates fourteen physiological races of Phytophthora capsici. Euphytica 162:23-30.

Granke, L. L., Quesada-Ocampo, L., Lamour, K., and Hausbeck, M. K. 2012. Advances in research on Phytophthora capsici on vegetable crops in the United States. Plant Dis. 96:1588-1600.

Guo, P. P., Zhu, L. S., Wang, J. H., Wang, J., Xie, H., and Lv, D. D. 2015. Enzymatic activities and microbial biomass in black soil as affected by azoxystrobin. Environ. Earth Sci. 74:1353-1361.

Hu, J., Pang, Z. L., Yang, B., Shao, J. P., Diao, Y. Z., Guo, J. G., Liu, Y. G., Lv, H. P., Lamour, K., and Liu, X. L. 2013. Genetically diverse long-lived clonal lineages of Phytophthora capsici from pepper in Gansu, China. Phytopathology 103:920-926.

Hu, M.-J., Grabke, A., Dowling, M. E., Holstein, H. J., and Schnabel, G. 2015. Resistance in Colletotrichum siamense from peach and blueberry to thiophanatemethyl and azoxystrobin. Plant Dis. 99:806-814.
Ishii, H., Fountaine, J., Chung, W. H., Kansako, M., Nishimura, K., Takahashi, K., and Oshima, M. 2009. Characterisation of QoI-resistant field isolates of Botrytis cinerea from citrus and strawberry. Pest Manage. Sci. 65:916-922.

Ishii, H., Fraaije, B. A., Sugiyama, T., Noguchi, K., Nishimura, K., Takeda, T., Amano, T., and Hollomon, D. W. 2001. Occurrence and molecular characterization of strobilurin resistance in cucumber powdery mildew and downy mildew. Phytopathology 91:1166-1171.

Jia, J. C., Ma, L., Fan, Z. J., Xia, Q., and Liu, X. F. 2008. Progress on study of resistance mechanism of strobilurin fungicides. Chin. J. Pestic. Sci. 10:1-9.

Jiang, Y. Q., and Wang, Z. Z. 2008. Sensitivity of Phytophthora capsici to azoxystrobin in Guangdong. Plant Prot. 34:99-103.

Jordan, D. B., Livingston, R. S., Bisaha, J. J., Duncan, K. E., Pember, S. O., Picollelli, M. A., Schwartz, R. S., Sternberg, J. A., and Tang, X. S. 1999. Mode of action of famoxadone. Pestic. Sci. 55:105-118.

Joseph-Horne, T., Hollomon, D. W., and Wood, P. M. 2001. Fungal respiration: A fusion of standard and alternative components. BBA-Bioenergetics. 1504: 179-195.

Kitchen, J. L., Frank, V. D. B., Paveley, N. D., Joseph, H., and Femke, V. D. B. 2016. The evolution of fungicide resistance resulting from combinations of foliar-acting systemic seed treatments and foliar-applied fungicides: A modeling analysis. PLoS One 11:e0161887.

Koç, E. 2017. Alleviation of Phytophthora capsici-induced oxidative stress by foliarly applied proline in Capsicum annuum L. Arch. Biol. Sci. 69: 733-742.

Lamour, K. H., Stam, R., Jupe, J., and Huitema, E. 2012. The oomycete broad hostrange pathogen Phytophthora capsici. Mol. Plant Pathol. 13:329-337.

Li, Z. J., Long, W. P., Zheng, J. R., and Lei, J. J. 2007. Isolation and identification of Phytophthora capsici in Guangdong province and measurement of their pathogenicity and physiological race differentiation. Hua Nan Nong Ye Da Xue Xue Bao 28:50-54.

Liu, P. Q., Wei, M. Y., Zhang, J. Z., Wang, R. B., Li, B. J., Chen, Q. H., and Weng, Q. Y. 2018. Changes in mycelia growth, sporulation, and virulence of Phytophthora capsici when challenged by heavy metals $\left(\mathrm{Cu}^{2+}, \mathrm{Cr}^{2+}\right.$ and $\left.\mathrm{Hg}^{2+}\right)$ under acid pH stress. Environ. Pollut. 235:372-380.

Ma, H. G., He, L. G., Zhang, H. L., Li, X. M., and Jiang, J. X. 2013. Physiological races of Phytophthora capsici and their sensitivity to dimethomorph in Jiangxi province. Acta Phytophylac. Sin. 40:374-378.

Matheron, M. E., and Porchas, M. 2000. Impact of azoxystrobin, dimethomorph, fluazinam, fosetyl-al, and metalaxyl on growth, sporulation, and zoospore cyst germination of three Phytophthora spp. Plant Dis. 84:454-458.

Miao, J. Q., Cai, M., Dong, X., Liu, L., Lin, D., Zhang, C., Pang, Z. L., and Liu, X. L. 2016. Resistance assessment for oxathiapiprolin in Phytophthora capsici and the detection of a point mutation (G769W) in PCORPl that confers resistance. Online publication. Front. Microbiol. 7:615.

Miao, J. Q., Dong, X., Lin, D., Wang, Q. S., Liu, P. F., Chen, F. R., Du, Y. X., and Liu, X. L. 2015. Activity of the novel fungicide oxathiapiprolin against plantpathogenic oomycetes. Pest Manage. Sci. 72:1572-1577.

Ojiambo, P. S., Paul, P. A., and Holmes, G. J. 2010. A quantitative review of fungicide efficacy for managing downy mildew in cucurbits. Phytopathology 100:1066-1076

Oliveira, S. C. D., Castroagudín, V. L., Maciel, J. L. N., Pereira, D. A. D. S., and Ceresini, P. C. 2015. Resistência cruzada aos fungicidas IQo azoxistrobina e piraclostrobina no patógeno da brusone do trigo Pyricularia oryzae no Brasil. [Cross-resistance to QoI fungicides azoxystrobin and pyraclostrobin in the wheat blast pathogen Pyricularia oryzae in Brazil]. Summa Phytopathol. 41:298-304.

Owati, A. S., Agindotan, B., Pasche, J. S., and Burrows, M. 2017. The detection and characterization of QoI-resistant Didymella rabiei causing Ascochyta blight of chickpea in Montana. Front. Plant Sci. 8:1165.

Pang, Z. L., Shao, J. P., Chen, L., Lu, X. H., Hu, J., Qin, Z. H., and Liu, X. L. 2013 Resistance to the novel fungicide pyrimorph in Phytophthora capsici: Risk assessment and detection of point mutations in CesA3 that confer resistance. PLoS One 8:e56513.

Qian, Z. H., Chen, C. J., Wang, J. X., and Zhou, M. G. 2006. Baseline sensitivity of different morpha of Phytophthora capsici Leonian to azoxystrobin. Acta Phytopathol. Sin. 36:322-327.

Ristaino, J. B., Madritch, M., Trout, C. L., and Parra, G. 1998. PCR amplification of ribosomal DNA for species identification in the plant pathogen genus Phytophthora. Appl. Environ. Microbiol. 64:948-954.

Sierotzki, H., Frey, R., Wullschleger, J., Palermo, S., Karlin, S., Godwin, J., and Gisi, U. 2007. Cytochrome $b$ gene sequence and structure of Pyrenophora teres and $P$. tritici-repentis and implications for QoI resistance. Pest Manage. Sci. 63:225-233.

Sierotzki, H., Wullschleger, J., and Gisi, U. 2000. Point mutation in cytochrome $b$ gene conferring resistance to strobilurin fungicides in Erysiphe graminis f. sp. tritici field isolates. Pestic. Biochem. Physiol. 68:107-112.

Stewart, T. M., Perry, A. J., and Evans, M. J. 2014. Resistance of Zymoseptoria tritici to azoxystrobin and epoxiconazole in the lower North Island of New Zealand. N. Z. Plant Prot. 67:304-313.

Sun, H. Y., Wang, H. C., Stammler, G., Ma, J. X., and Zhou, M. G. 2010. Baseline sensitivity of populations of Phytophthora capsici from China to three carboxylic acid amide (CAA) fungicides and sequence analysis of cholinephosphotransferases from a CAA-sensitive isolate and CAA-resistant laboratory mutants. J. Phytopathol. 158:244-252. 
Thind, T. S., Mohan, C., Raj, P., and Arora, J. K. 2004. Activity spectrum of strobilurins, a new generation of ecofungicides, against some fungal pathogens. Indian Phytopathol. 57:104-106.

Vaghefi, N., Hay, F. S., Kikkert, J. R., and Pethybridge, S. J. 2016. Genotypic diversity and resistance to azoxystrobin of Cercospora beticola on processing table beet in New York. Plant Dis. 100:1466-1473.

Wood, P. M., and Hollomon, D. W. 2003. A critical evaluation of the role of alternative oxidase in the performance of strobilurin and related fungicides acting at the Qo site of complex III. Pest Manage. Sci. 59:499-511.
Yang, M. Y., Cao, J. F., Li, X. D., Sun, D. W., Wang, Y. C., and Zhao, Z. J. 2009. Molecular diagnosis and characterization of blight disease pathogen on pepper in Yunnan. Acta Phytopathol. Sin. 39:297-303.

Zhao, J. J., Li, H. X., Wang, W. Q., Han, X. Y., Ma, Z. Q., Zhang, J. L., and Zhang, X. F. 2008. Resistance detection and assessment of resistance risk of Cladosporium fulvum to azoxystrobin. Chin. J. Pestic. Sci. 10:47-52.

Ziogas, B. N., Baldwin, B. C., and Young, J. E. 1997. Alternative respiration: A biochemical mechanism of resistance to azoxystrobin (ICIA 5504) in Septoria tritici. Pestic. Sci. 50:28-34. 